\title{
Improvement of Educational Process on the Basis of Use of New Information and Pedagogical Technologies
}

\author{
Elena A. Bezglasnaya1 \\ Sergei B. Gorbatov² \\ 1. Samara State University of Economics, Russia, 443090, Samara, Sovetskoi Armii Street, 141 \\ 2. Samara State University of Economics, Russia, 443090, Samara, Sovetskoi Armii Street, 141 \\ Correspondence: Elena A. Bezglasnaya, Samara State University of Economics, 443090 \\ Russia, Samara, Sovetskoi Armii Street, 141, Email: ElenaBezglasnaya@yandex.ru \\ Sergei B. Gorbatov, Samara State University of Economics, 443090, Russia, Samara \\ Sovetskoi Armii Street, 141, Email: gorbatovsv@gmail.com
}

Doi:10.5901/mjss.2015.v6n6s3p410

\begin{abstract}
The paper represents modern information technology, which is successfully applied in the pedagogical process of educational institutions. The authors analyze possibilities of modern platforms for massive open online courses, and analyze the functionality of the platforms Moodle and OpenEDX. The platform OpenEDX has opened new opportunities for schools to implement massive online courses, at the same time Moodle is a leader in the field of platforms to work with traditional inneracademic online courses. In addition, the article presents two universal mobile work tools to work with large flows of students, to analyze their effectiveness. The findings allow us to recommend these tools for widespread use in the educational process, so that a lecturer could obtain an instant feedback from listeners. The main conclusion of this work - in the near future massive open online courses may completely change the traditional pedagogical approaches adopted in universities. Global competition for students will form a new order in the global educational system. At the same time, in the near future e-learning will not be able to replace traditional models of education. Teachers, keeping up with the times, will need to find a balance between traditional teaching approaches and possibilities of modern information and educational technology.
\end{abstract}

Keywords: communications in educational process, feedback, plikker, mobile scanner.

\section{Introduction}

The education system, as well as all other institutes of social development, are subject to influence of external factors. Total globalization that results in openness and availability of higher education creates threat to a regional education system.

Leading world rating universities work on projects that allow students, who are in every spot on the globe, to study at the best teachers of prestigious higher education institutions, without leaving the house.

The procedure is simple. The person who are interested to gain the diploma, for example, MIT or Stanford University, is registered on a special online educational platform and signs up for those courses which are included in the curriculum of the preferred speciality. A student chooses a convenient order and speed of studying disciplines. An online courses structure is universal. Usually it contains some information about course authors and administrators, and also their contact information. Besides it includes the curriculum with developed key issues with the indication of how much time should be spent on each subject; a set of competences which a listener should have after completing the studying; list of main and additional literature, and also reference to materials necessary for successful disciplines studying; system of tests on each course subject and a task of total certification; thematic forum at which listeners can communicate on different issues as with course administrators, and between each other.

\section{Mass Open Online Courses}

Key elements of an open online course are video fragments that last about from 6 to 12 minutes each. For all issues from the program authors record video material, and supplement it not only with the presentation which can be kept on a personal computer, to print and use it as a notebook for notes, but also necessary additional files. Each subject of the 
curriculum is followed by about ten videos by fragments, which last from one to two hours. To obtain the certificate a listener has to perform current and final tasks within the established deadlines.

The set of certificates can be shown in a higher education institution that realizes policy of passing credits for online courses. The diploma can be issued to a listener by the special solution of a certification commission; this diploma doesn't differ from the diploma of full-time tuition students. Thus, the students living in every spot on the globe can not spend time to obtain a study visa to pass a procedure of competitive matriculation to prestigious specialities, spend money to pay education, transportation, housing, studying materials, etc.

The speed of distribution of similar pilot projects is very high. The first mass online educational platform appeared in 2008. Although historians claim that a peculiar Socrates' statements interpretation can criticize written texts: "they speak the same to all readers therefore they teach nobody. It's not possible to study without personalization!" ... "There is an opinion that distance education dates back to the apostle Pavel times who sent his lections to temples of different countries" ... "The first distant courses appeared in the middle of the XIX century, and mass education on video lectures was introduced during the USSR times"1. Now nobody is surprised by simulators by means of which drivers of automobile, cargo and special transport are trained as well as pilots and cosmonauts, difficult surgeries are performed at distance.

In 2012 the system of online education was widely adopted thanks to emergence of several convenient electronic platforms that were developed by separate initiative groups and creative groups of American universities. In 2015 the announcement of Russian-speaking courses drew attention of more than 23 thousand people. The geography of listeners captured all countries of the world, including African countries, Saudi Arabia, Japan, Mexico, the USA and many others².

\section{Traditional Electronic Courses}

In this situation threat of loss of regional higher education institutions importance is obvious. The teachers who have the authority of "gold mine of information" for local students can gradually turn into mentors, tutors of those online courses which will receive high reputation and will win much popularity with listeners. It is possible to be prepared for this inevitable process in advance. There are two variants. The first: a higher education institution follows adaptation strategy, accepting reality as givenness, agreeing with similar changes, "following the stream". The second variant is connected with advancing development, creation of own courses and attraction of long-term attention of potential students. First way is risk-free and simple. The second is risky and difficult, for this reason it has special interest.

Indisputable fact is active introduction of open mass online courses in modern reality. Such courses advance knowledge in masses, allow education institutions to look for gifted students, besides open online courses is a good advertizing for higher education institutions. But there is the reverse side of the medal. Development of open mass online course is expensive and long process. To develop all disciplines of an education program as open courses is not effective and expensive.

There will always be narrow-targeted disciplines on regional and higher institution level. Besides process of creation of traditional online courses and mass courses is necessary to be developed on the example of an experimental group. It is more logical when students of an education institution refer to an experimental group.

Due to aforesaid, we consider that on a wave of popularity of open mass online courses we shouldn't forget about traditional intra higher institution electronic courses. Unfortunately, today there are no strict standards of mass electronic courses. There are not enough platforms that specialize on mass courses. Among open systems special, the Open EDX platform is the most popular. There are more platforms that specialize on traditional online courses.. One of such platforms is Moodle. Moodle is an education management system with an open source code. Now it is very popular. Today more than sixty thousand (from them about one thousand from Russia) education institutions use this system more than in two hundred countries of the world.

The main advantage of Moodle is various functional opportunities. This system expands in an open source code; allows to organize training in an active form; has many opportunities for communication; has opportunity to work with any assessment system; keeps full information on students and teachers work; conforms to developed standards; provides work possibility to people of various educational level.

As for purposes realization of social constructivism theory the Moodle system comprises a large number of interactive tools by means of which it is possible to realize listeners communication with each other effectively and with

\footnotetext{
1 On research EDUTAINME materials "Encyclopedia of educational technologies: 10 amazing facts from education history: from Socrates to Coursera" It is published: 02.04.2015 [Electronic resource]. Mode of access of http://www .edutainme.ru/post/edtech-history/. 2 Information from personal experience participations in online education of NIU HSE provided by authors of courses at open forums
} 
the teacher on the basis of tasks that are performed collectively, i.e. it acts as a social network, but with a bias in educational process. Today functions that are necessary for mass courses are integrated into Moodle, but unfortunately, as a platform of mass courses it will likely not be able to be used soon. On the one hand, Moodle contains big functionality that other mooc-focused platforms don't have, on the other hand technical restrictions that are left from outdated basic platform do not allow to develop really big and effective mooc-platform.

At the same time Moodle is one of the most effective development tools, a maintenance tool of traditional online courses and an educational tool. The system supports Wiki pages mechanism that allows to write common documents with group of students by means of a simple language of marking in a browser window, also the system can contain active modules, namely: questionnaires, glossaries, tasks, classes attendances, lectures, polls, workbooks, seminars and many others. The Moodle system supports a large number of standard test tasks and effective tools of testing. The important feature is various social and multimedia services integration.

The main objective of Moodle is granting maximum tool opportunities for management and assistance of educational process. The Moodle is comparable on the level of its opportunities with any commercial education management system. The Moodle system is written in PHP programming language with use of SQL database, the Moodle completely meets the SCORM standard.

The education system that is constructed on the basis of the Moodle can be rather compact (one teacher - some groups of students), and huge (hundreds of teachers - one thousand students).

A standard electronic course in a system can contain interactive lectures (for full-time students they are as additional theoretical material), intermediate and final tests, tasks for homework, practical and laboratory works, reports on academic progress, system of score and rating assessment, additional stimulating elements, for example pictograms. As a result within the system, the complex of "live" materials on a subject is formed where students reports, teachers reviews, tests results are stored. All these materials supplement originally created electronic course. In contradiction from an educational and methodical complex on a hard copy such electronic course is self developed over time. For example, if within laboratory or independent work we give a task to students to review terms on a certain topic and on the basis of this review we create a glossary, and consequently terms from this glossary can be imported to a main course glossary that will allow them to contact texts of interactive lectures automatically. Such approach gives the chance to a teacher to support an electronic course in a current state since the materials placed in it "are rather actively moderated" by more active students that allows to get rid of technical and typographical errors etc.

One more popular Moodle tool is interactive tasks. Moodle allows to organize tasks of many kinds and types. The most frequent options of tasks are a task in a form of an essay, a task out of site and a task in a form of a file. For example, to keep results of students laboratory works it is possible to use a task in a form of a file. After laboratory work completion that is placed on the website, students have to send the report, a teacher checks a report and after it he can leave a comment for a student and either assess work, or send it back for revision. Students work results are automatically placed in their score and rating card.

Platform functionality goes far beyond the opportunities described by standards and at the same time as well as the platform Open EDX, the Moodle allows to transfer electronic courses only between its copies. This restriction is necessary to overcome as soon as possible. For example, opportunity to transfer an electronic course from the Moodle platform to the Open EDX platform will allow to adapt a traditional online course to tasks of a mass open course.

\section{Traditional Educational Technologies}

Global competitive fight for students is developing in a virtual space now. However internal communication of students and teachers will not lose its value and will take a worthy place in educational process of future specialists.

Students of different courses are different students, with different motivation. The first-year student is a yesterday school graduate. The first months of academic year are hard for him, he is getting used to a new education system till winter exams, builds communication process with administration bodies and teachers. He gradually gets rid of a habit to worship as it was at school, of an imposed teacher authority and gradually turns into a partner, an equal participant of educational process. A last year student is already a personality who is able to make weighed decisions, he rationally approaches to educational trajectory formation.

To provide productive education in a higher education institution the solution of many problems is important. It is formation of steady educational students motivation. Therefore, not only lecture content is important, but also how the lecturer is read. Many years later graduates will remember those details of an educational material which are presented in a memorable form and are accompanied by clear examples. The best teacher is not a scientist, but a person who can deliver a studied course to each listener in-depth. Methods of a professional speaker are relevant here, and effective 
management techniques of audience attention and even acting skills are urgent.

The edge between a performance and a working situation is strictly defined by a teacher when he sets a task not only to transfer knowledge, carrying out his work load, but also to check as far as material was acquired by a listener. The traditional way is testing, checking, even if in an electronic environment there is writing off and information leakage ... The situation is aggravated when there are many students in the classroom. And if there are hundreds of students, a problem of feedback, adequate reality, is hard to solve.

\section{Modern Technologies of Feedback in Pedagogical Process}

However, there are techniques and tools which allow to receive quality feedback from students in real time in the classroom with school desks and chairs. For modern youth life is impossible without various electronic devices: cell phones, smart phones, tablets, etc. It is adopted to call them by an Anglicism "device" (from English "device" that in translation into Russian means an artificial object with an internal structure created to perform certain functions). Teachers, for example, of American higher education institutions in increasing apply techniques of "turned classes" and use different tools to transfer knowledge to a large audience. A set of tools, software, technical support are extremely expensive. Search of available analogues had two results.

Instruments of effective communication and quality feedback were found in supplements to modern devices on the Android and IOS platforms.

As earlier in Russian literature the translation of the first tool was not found, we will call it "plicker". The English original name is "plicker". Visually a plicker is a square that has its number, parties definitions by letters "A", "B", "C", "D" and special cuts on the parties and inside, which resembles QR (fig. 1).

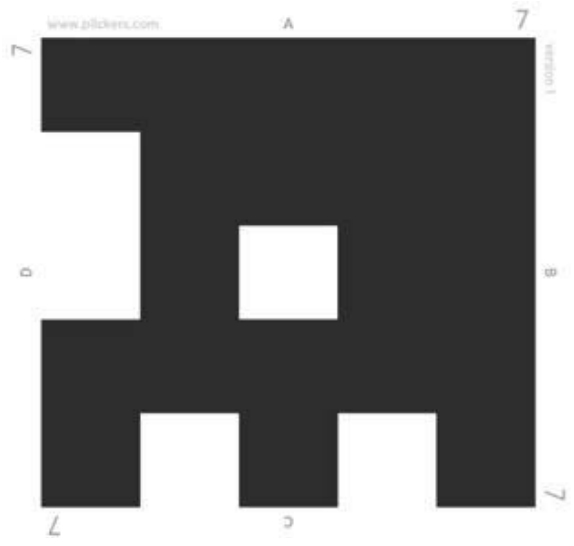

Figure 1. Example of a plicker ${ }^{3}$

Cuts by small squares or long rectangles can be on one or several parties. The correct reading of letters makes to turn a square a certain party up. Software developers give 63 different options of plickers. To apply this tool a teacher can download the software on his device that has a camera. Then on the site of this tool developers it is necessary to create a group profile. A serial number is assigned to each student of the group and its unique plicker is fixed. If there are more than 63 students, a stream breaks into groups and a procedure repeats. To prepare for classes a teacher forms a bank of thematic questions and to each of them, there are not more than four versions of answers among which there is one correct at least. (Practice shows that it is better if only one of offered options is correct). The questions that a teacher wants to ask students, are evenly distributed on time. For example, it is better to ask the first question five minutes after the lesson starts. Having recorded result, presence and absence of students at the lesson is checked at the same time. The last question can be asked at the end of the lesson, so you can find out who was present at the lesson. Other questions can be asked to check after completion of each structural part.

Assessment happens rather easily. A teacher on his device opens the supplement and that question that he wants

${ }^{3}$ Authors of article follow policy of conscientious use of site materials https://www .plickers.com 
to ask listeners at that moment. He asks a question and says versions of answers (or shows them on a presentation slide), gives time to consider the answer and suggests that students should lift a plicker over their heads, having placed a letter by which the party is defined, corresponding, in their opinion, to a right answer, in a correct position. Then a teacher switches on a camera and, using the program, scans the audience. As soon as the camera finds a plicker, it remembers it, defines plicker's possession to that student, whose surname is in the list of the group, and fixes his result. Time for all audience assessment and receiving results takes some minutes.

The second instrument of effective communication is a mobile scanner "Quick key". It is also a supplement for modern devices. As well as for plickers the list of students is formed on a special site, a unique number is assigned to everyone. For complex examination students are given cards for answers (fig. 2). This procedure reminds Unified State Examination according to forms, and their filling.

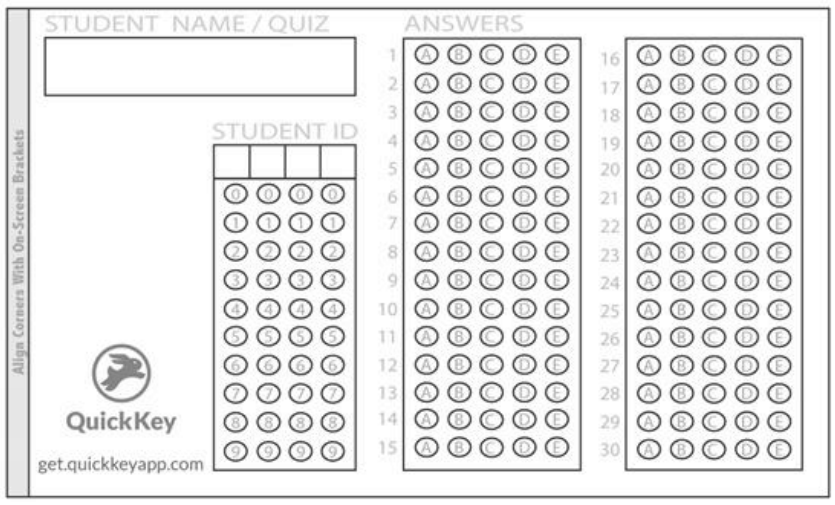

Figure 2. Example of answers to test questions of complex work

A student receives a task, fills in a answers form. The teacher scans his answers and instantly receives a result. In an automatic mode all results are processed and entered in a final electronic sheet. Time to check one work takes the same time as to take a photo.

The offered tools were successfully approved at the lessons where there are big flows of students. After the first lesson attendance increased sharply, and the working environment was created. All students, even on "remote desks", not only listened attentively and perceived information, but also asked questions to clarify something. Lectures turned into constructive thematic dialogue that led to complete information acquiring. Plickers and a mobile scanner allowed to reduce teacher's time to check attendance, current and residual knowledge, to sum up. One of important results is a creation of an objective knowledge assessment system. These tools application allowed minimizing, on the one hand, prejudiced teacher attitude, and it gives a chance to students to accumulate knowledge.

We can refer the following items to the restrictions of this software products use. Taking into consideration all system advantages it cannot be integrated into common information and education environment of education institution. Each time when a teacher begins to work with a new group he has to create a list of pupils on the site of a system to introduce questions after classes, to analyze work results. As for use of unified information and education environment it would be much more effective to use a unified students base who are stored in an education management system that would reduce time of a preparatory stage. Besides It would be effective to have possibility to import students results from external systems in a unified higher institution education management system.

\section{Conclusion}

As conclusions to the article we can mark the following. Development of open mass online courses is positive in many respects in pedagogical environment of traditional higher education institutions. Global competition for students in the next years will allow creating a new order in a world educational system. At the same it is impossible to forget that electronic education cannot completely replace traditional educational models. We do not need to look for educational approaches, it is necessary to try to use the best in all approaches, to mix traditional pedagogical approaches with opportunities of modern information and pedagogical technologies. 


\section{References}

Wellesley is the first liberal arts college to join Harvard and MIT's online learning collaborative, edX//Wellesley College of 04.12.2012 http://new .wellesley.edu/news/stories/node/31615

Tamar Lewin New York Times 02/05/2012 Harvard and M.I.T. Team Up to Offer Free Online Courses http://www.nytimes.com/ 2012/05/03/education/harvard-and-mit-team-up-to-offer-free-online-courses.html? $\mathrm{r}=0$

R. Knight Free, high-quality and with mass appeal//Business Education 22/10/2012 http://www .ft.com/cms/s/2/73030f44-d4dd-11e19444-00144feabdc0.htm|\#axzz2A9qvk48A

Bezglasnaya E.A. Problems of ensuring competitiveness of higher education institutions and strategy of their activity in the conditions of regional competition. / University management: practice and analysis. 2006. No. 9. Page 34.

Bezglasnaya E.A. Services of educational institutions: essence, features of their competitiveness / Vistnik of Samara State University of Economics. 2006. No. 6. Page 181-185.

Bezglasnaya E.A., Sevastyanova S. A. Improvement of educational programs system in the field of economy in the context of interdisciplinary interaction / Vestnik of Samara State University of Economics. 2014. No. 4 (114). Page 153-156.

Teaching social and humanitarian subjects in higher education institutions of Russia / Arapov M.V., Ionin L.G., Bezglasnaya E.A., and other / condition, problems, prospects: Analytical report / editor originator L. G. Ionin. Moscow, 2003.

Gorbatov, S. V. Learning management systems in the course of bachelors training. In the volume: Modernization of professional education: new tendencies in management of innovative development of higher education institutions of economics. Materials of All-Russian scientific and practical conference of students, graduate students and young scientists. Editorial board: G. R. Hasayev, S. I. Ashmarina, E. P. Pecherskaya (editor-in-chief). 2013. Page 100-104.

Gorbatov, S. V. Use of education management systems in the course of the independent students work organization. / S. V. Gorbatov /I Materials of All-Russian scientific and practical conference of students, graduate students and young scientists "Modernization of professional education: new tendencies in innovative development management of higher education institutions of economics". 2013. - Page 99-102. 